\title{
Festival Sebagai Media Komunikasi Dalam Membangun Citra Destinasi Wisata Budaya Di Sumenep
}

\author{
Mohammad Insan Romadhan ${ }^{\mathrm{a}, 1, *}$

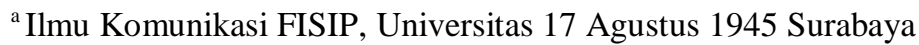 \\ ${ }^{1}$ Email: insanromadhan@untag-sby.ac.id* \\ * corresponding author
}

ARTICLE INFO

Keywords

Image Building,

Management Impression

Theory,

Destinations Culture,

Sumenep

\section{ABSTRACT}

Sumenep with its cultural diversity has the potential to become a destination visited by many tourists. This is the duty of the Sumenep regional government to be able to better introduce and build an image as a tourist destination in Indonesia. So that researcher are interested in examining how the Sumenep Tourism and Culture departement build the image Sumenep of a tourist destination. The theory used in this research is management impression theory, Laswell and Aristoteles Communication Model. The research method uses a qualitative approach, with a type of descriptive research and using a case study method. Research informant is head of promotion in the tourism and cultural departement of Sumenep. The data collection technique in this research used interviews, observation and documentation. The result of the research on the process of building the image of the efforts made by showing and displaying the Sumenep cultures, for example kerapan sapi, sapi sonok, tong-tong music, saronen music to presented to the public. So the impression public would perceive as expected. Selection of the festival as a communication channel for the delivery of a message is deemed appropriate to the interests of public. For self presentation strategy is a strategy of self-promotion

\begin{abstract}
ABSTRAK
Sumenep dengan keanekaragaman budayanya berpotensi menjadi destinasi yang banyak dikunjungi wisatawan. Ini adalah tugas pemerintah daerah Sumenep untuk dapat lebih memperkenalkan dan membangun citra sebagai tujuan wisata di Indonesia. Sehingga peneliti tertarik meneliti bagaimana departemen Pariwisata dan Kebudayaan Sumenep membangun citra Sumenep dari destinasi wisata. Teori yang digunakan dalam penelitian ini adalah teori kesan manajemen, Laswell and Aristoteles Communication Model. Metode penelitian menggunakan pendekatan kualitatif, dengan jenis penelitian deskriptif dan menggunakan metode studi kasus. Informan penelitian adalah kepala promosi di departemen pariwisata dan budaya Sumenep. Teknik pengumpulan data dalam penelitian ini menggunakan wawancara, observasi dan dokumentasi. Hasil penelitian tentang proses membangun citra dari upaya yang dilakukan dengan menunjukkan dan menampilkan budaya Sumenep, misalnya kerapan sapi, sapi sonok, musik tong-tong, musik saronen untuk disajikan kepada publik. Sehingga kesan publik akan mempersepsikan seperti yang diharapkan. Pemilihan festival sebagai saluran komunikasi untuk penyampaian pesan dianggap sesuai dengan kepentingan publik. Untuk strategi presentasi diri adalah strategi promosi diri
\end{abstract}

\section{PENDAhULUAN}

Budaya Negara Indonesia yang dikenal melimpah ruah merupakan anugrah yang diberikan alam yang belum tentu dimiliki oleh negara lainnya. Tercatat sebanyak 8065 budaya yang dimiliki oleh Indonesia (Kemdikbud, 2018). Selain itu pada tahun 2018 Indonesia melalui Kementerian Pendidikan dan Budaya kembali menetapkan sebanyak 225 warisan budaya tak benda (WBTB), berikut kutipan artikelnya:

Jakarta, Kemendikbud --- Sebagai bentuk perlindungan dan pelestarian terhadap kekayaan budaya di Indonesia, pemerintah melalui Kementerian Pendidikan dan Kebudayaan (Kemendikbud) kembali 
menetapkan 225 Warisan Budaya Takbenda (WBTB) dalam acara Apresiasi Penetapan Warisan Budaya Takbenda Tahun 2018. (Kemdikbud, 2018)

Berdasarkan berita pada artikel tersebut menunjukkan besarnya potensi budaya di Indonesia untuk dikelola ke dalam berbagai hal, dengan bertambahnya 225 Warisan Budaya Takbenda (WBTB), maka jumlah Warisan Budaya Takbenda (WBTB) yang di miliki Indonesia tercatat sebanyak 819 Warisan Budaya Takbenda (WBTB). (Kemdikbud, 2018). Selain itu Indonesia melalui Kementerian Pendidikan dan Kebudayaan juga mematenkan 652 bahasa daerah yang ada di Indonesia (Kemdikbud, 2018) dan tercatat juga berdasarkan Summer Institute of Linguistics menyampaikan bahwa jumlah bahasa yang ada di Indonesia aktif digunakan atau dituturkan sebanyak 707 bahasa dari total sebanyak 719 bahasa daerah, berikut kutipan artikelnya:

Summer Institute of Linguistics menyebut jumlah bahasa di Indonesia sebanyak 719 bahasa daerah dan 707 di antaranya masih aktif dituturkan. Sementara itu (Kemdikbud, 2018)

Berdasarkan informasi yang dipublikasikan oleh Kementerian Pendidikan dan Budaya tersebut menunjukkan betapa kayanya budaya Negara Indonesia ini dan hal tersebut menunjukkan potensi besar yang bisa dikelola dari budaya untuk sektor pariwisata dengan menjadikan budaya tersebut sebagai daya tarik wisatawan agar mau berkunjung ke Indonesia. Hal tersebut sudah banyak terbukti dengan melihat besarnya animo wisatawan untuk berkunjung ke Bali.

Siapa yang tidak kenal Bali? Limpahan alam dan budayanya mampu menyihir wisatawan untuk tidak bosan berkunjung ke Bali berkali-kali. Seharusnya dengan limpahan alam dan budaya yang tersebar di seluruh pelosok Indonesia, bukan tidak mungkin Indonesia menciptakan Bali-bali yang lain. Lombok salah satunya, destinasi ini mulai dijadikan alternatif oleh wisatawan selain Bali. Dan salah satu destinasi yang sedang bergeliat adalah Sumenep yang terletak di Pulau Madura. Berbagai keindahan alam dan kekhasan budayanya menjadikan Sumenep layak untuk dijadikan destinasi tujuan wisata.

Sumenep yang berjarak sekitar $900 \mathrm{~km}$ dari ibukota Indonesia ini memiliki bermacam-macam budaya, yang paling terkenal adalah budaya kerapan sapi, dimana budaya tersebut menyajikan adu lari cepat dari sapi yang biasanya ditunggangi oleh anak kecil. Ada juga budaya sapi Sonok, dimana dalam budaya ini menyajikan kontes kecantikan sapi betina yang rias sedemikian rupa. Selain itu ada budaya saronen dimana budaya ini merupakan budaya musik asli Sumenep yang menampilkan Sembilan instrument alat musik. Ada juga budaya Tong-tong, dimana budaya ini juga merupakan budaya musik yang keberadaan diawali karena kebiasaan masyarakat Sumenep yang gemar berpatroli dengan memainkan musik Tong-tong ketika bulan Ramadhan dengan tujuan untuk membangunkan orang sahur.

Dengan potensi yang dimiliki Sumenep Madura layak untuk berharap akan menjadi destinasi yang banyak dikunjungi oleh wisatawan. Tentunya ini menjadi tugas pemerintah daerah Sumenep untuk dapat lebih mengenalkan dan membangun citra sebagai destinasi wisata yang layak untuk dijadikan destinasi wisatawan. Kepala bagian promosi dari bagian Dinas Pariwisata dan Kebudayaan Sumenep Ronny Arif Y menyampaikan:

Tantangan Pariwisata di Sumenep karena wilayah Sumenep merupakan tempat tujuan, bukan tempat transit seperti banyuwangi contohnya yang dimana orang yang punya tujuan ke Bali berpotensi juga akan melewati banyuwangi, sedangkan di Sumenep bukan merupakan daerah transit sehingga hanya orang yang benar-benar akan menuju Sumenep saja yang akan berkungjung.

(Ronny Arif, Kelapa Bagian Promosi)

Ronny juga menyampaikan bahwa hal tersebut menjadi tantangan tersendiri untuk memajukan pariwisata di Sumenep Madura ini. Karena itu untuk membangun citra bahwa Sumenep mempunyai budayabudaya yang menarik untuk dikunjungi, maka Pemerintah Daerah setempat sering mengadakan festivalfestival untuk mengenalkan budaya-budayanya kepada masyarakat luas. Di tahun 2018 ini Sumenep menggembor-gemborkan Visit Sumenep dengan membuat Calender of Event Visit Sumenep 2018, dimana salah satu rangkaian acaranya yaitu menjadi tuan rumah Festival Keraton dan Masyarakat Adat ASEAN (FKMA) 2018.

Dengan membuat suatu acara-acara tersebut secara tidak langsung akan lebih mampu untuk mendapatkan perhatian dari masyarakat luas. Artinya dalam studi ilmu komunikasi pesan yang ingin kita sampaikan tidak hanya dapat disampaikan secara langsung, akan tetapi juga dapat dilakukan dengan menggunakan media seperti pamflet, brosur, televisi, radio, baliho, suguhan acara seperti festival dan lain sebagainya. Seperti model komunikasi yang disampaikan oleh Lasswell dimana untuk mempelajari proses komunikasi yaitu dengan cara menjawab pertanyaan: Who, Says What, In Which Channel, To Whom, With What Effect, artinya dalam elemen "In Which Channel? (pada saluran apa?)" menunjukkan bahwa saluran 
komunikasi atau media dalam penyampaian pesannya dapat menggunakan media apa saja sepanjang hal tersebut layak untuk dijadikan media komunikasi.

Pada kasus upaya pemerintah daerah Sumenep dalam membangun citra destinasi wisata budaya agar mampu menarik wisatawan untuk berkunjung, selain dengan menggunakan media-media konvensional seperti surat kabar, radio lokal dan baliho-baliho, upaya tersebut juga banyak dilakukan dengan memanfaatkan festival. Sepanjang tahun 2018 seperti yang tercantum pada Calender of Event Visit Sumenep 2018 tercatat hampir semuanya merupakan pageralan acara. Berdasarkan hal tersebut peneliti tertarik untuk meneliti mengenai festival sebagai media komunikasi dalam membangun citra destinasi wisata budaya di sumenep.

\section{KAJIAN LITERATUR}

Pada penelitian ini kajian literatur yang digunakan sebagai pisau analisis adalah teori impression management, dimana teori ini mengatakan bahwa dalam interaksi sosial setiap individu berupaya menampilkan gambaran dirinya atau konsep dirinya di depan orang lain, hal tersebut dapat dikatakan sebagai upaya individu yang secara sengaja menggunakan komunikasi untuk menciptakan impresi yang diinginkan dari orang lain terhadapnya. (Johannson dalam Kriyantono, 2014). Karena manajemen impresi ini terkait dengan cara individu dalam mempresentasikan dirinya, maka Rosenfeld, Giacalone \& Riordan (1994) menyebutnya sebagai teori presentasi diri.

Sama halnya dengan individu, suatu organisasi pun dapat menggunakan teori manajemen impresi ini untuk dapat mempresentasikan dirinya kepada khalayaknya. (Kriyantono, 2014). Artinya untuk membangun impresi khalayak terhadap suatu organisasi maka juga diperlukan upaya untuk mempresentasikan organisasinya. Pada teori manajemen impresi, komunikasi digunakan untuk mengelola impresi orang lain terhadap diri orang tersebut (Goffman, 1956). Goffman menjelaskan komunikasi yang digunakan dibagi menjadi dua bagian, pertama yaitu komunikasi verbal yang relatif lebih mudah bagi individu untuk mengelola dan memanipulasi. Sehingga cenderung menghasilkan pesan yang sengaja disampaikan (expression given on). Kedua yaitu komunikasi non verbal yang relatif lebih sulit untuk dikelola dan dimanipulasi dan sering terjadi diluar kesadaran, sehingga cenderung menghasilkan pesan yang disembunyikan atau tidak sengaja disampaikan (expression given off)

Dalam konteks membangun citra di dalam teori manajemen impresi, komunikasi digunakan untuk mengelola impresi publik terhadap apa yang ingin dicapai organisasi tersebut. Sehingga organisasi juga dituntut untuk mengelola pesan baik itu pesan verbal yang relatif mudah untuk dimanipulasi dan pesan non non verbal yang relative sulit untuk dimanipulasi. Pesan tersebut disampaikan dengan tujuan untuk dapat membangun citra yang baik terhadap organisasinya. Edward Jones dalam kriyantono (2014) mengaplikasikan teori penetrasi diri dengan mengemukakan lima kategori atau tipologi strategi presentasi diri yaitu strategi ingratiation (menyenangkan orang lain), strategi self-promotion (promosi diri), strategi exemplification (sebagai contoh), strategi supplication (self-handicapping) dan strategi intimidation.

Dalam menentukan strategi komunikasi maka perlu diperhatikan beberapa komponen yang ada dalam proses komunikasi. Strategi komunikasi yang diartikan sebagai perencanaan dan manajemen dalam mencapat suatu tujuan yang kemudian diimplementasikan dalam bentuk tindakan komunikasi berperan penting dalam keberhasilan suatu upayan ataupun program dalam mencapai target yang ingin dicapainya. Berbicara mengenai strategi komunikasi maka komponen-komponen yang perlu diperhatikan adalah komponen yang dikemukakan dalam teori komunikasi Laswell. (Romadhan, 2018)

Dimana dalam model komunikasi ini untuk mengetahui apa saja yang menjadi komponen-komponen komunikasi maka harus menjawab beberapa pertanyaan seperti Who Says What In What Channel To Whom With What Effect? (Moerdijati, 2012). Yang dapat dijelaskan sebagai berikut, seperti Who? Siapa komunikatornya?, Says What? Pesan apa yang dinyatakan?, In What Channel? Media apa yang digunakan?, To Whom? Siapa komunikannya?, With What Effect? Efek apa yang diharapkan?.

Berdasarkan dari model Laswell tersebut dapat di implementasikan dalam merumuskan strategi komunikasi, dimana kita dapat menentukan komponen-komponen dari apa yang disampaikan Laswell baik itu dalam menentukan komunikator, pesan, media, komunikan dan feedbacknya. Seperti dalam model komunikasi Aristoteles misalnya dimana model tersebut menekankan komunikasi persusif dengan adanya komponen komunikasi pesan dan komunikan. Pada model komunikasi Aristoteles ini agar komunikasi persuasif berjalan dengan lancar, maka harus memperhatikan etos, pathos dan logos dari komunikator. (Mulyana, 2016) 
Penggunaan teori dalam penelitian ini, peneliti akan mengkaji data dari lapangan mengenai apa yang dilakukan oleh Dinas Pariwisata dan Kebudayaan dalam membangun citra destinasi wisata budaya dengan menggunakan teori manajemen impressi dalam hal cara mempresentasikan Sumenep. Sedangkan model komunikasi Laswell peneliti gunakan untuk mengkaji mengenai strategi komunikasi dalam penggunaan festival sebagai media komunikasi.

\section{METODE PENELITIAN}

Pada penelitian ini menggunakan pendekatan kualitatif, dimana prosedur penelitian ini memiliki ciriciri induktif yang dipengaruhi oleh pengalaman sang peneliti dalam mengumpulkan dan menganalisis data (Cresswell, 2015). Jenis penelitian yang digunakan menggunakan jenis penelitian deskriptif dimana jenis penelitian ini bertujuan untuk membuat deskripsi secara sistematis, faktual dan akurat tentang fenomena pada suatu objek penelitian (Kriyantono, 2010). Metode yang digunakan adalah studi kasus, dimana studi kasus adalah salah satu metode dalam pendekatan kualitatif yang penelitinya mengeksplorasi kehidupannyata, sistem terbatas kontemporer (kasus) atau beragam sistem terbatas (berbagai kasus), melalui pengumpulan data yang detail dan mendalam yang melibatkan beberapa sumber informasi. Informan penelitian ini adalah kepada bagian promosi pada dinas pariwisata dan kebudayaan Sumenep.

Adapun untuk teknik pengumpulan datanya dalam penelitian ini menggunakan wawancara, observasi dan dokumentasi yang dimana ketiga alat pengumpulan data ini digunakan untuk menggali data dalam menjabarkan permasalahan dalam penelitian. Teknik keabsahan data menggunakan triangulasi sumber, dimana data yang di dapat menggunakan teknik pengumpulan data yang sama dari informan yang berbeda (Moleong, 2013). Sedangkan untuk analisis data menggunakan teknik analisis komparatif konstant (Wimmer \& Dominic, 2000), dimana tahapan analisisnya yaitu menempatkan data kedalam kategorikategori, kemudian memperluas kategori tersebut dan mencari hubungan antar kategori untuk diintegrasikan kepada struktur teoretid yang koheren.

\section{HASIL DAN PEMBAHASAN}

Upaya dalam membangun citra destinasi wisata di Sumenep khususnya destinasi wisata budaya sudah intens dilakukan Dinas Pariwisata dan Kebudayaan Sumenep, hal tersebut disampaikan oleh Ronny Arif selaku Kelapa Bagian Promosi, berikut kutipan wawancara:

Kami melakukan berbagai upaya dalam mengenalkan destinasi wisata di Sumenep ini, salah satunya melalui acara-acara festival. Apalagi ditahun 2018 ini kami menyiapkan berbagai macam acara dan festival yang dikemas dengan tema visit sumenep 2018. (Wawancara, Ronny Arif, Kepala Bagian Promosi)

Berdasarkan kutipan hasil wawancara dengan kepala bagian promosi tersebut jelas bahwa Sumenep sedang gencar-gencarnya melakukan upaya-upaya dalam mengenalkan sekaligus membangun citra destinasi wisatanya. Selain itu mengenai upaya dalam mengkonsep hal apa yang harus ditekankan pada masyarakat mengenai citra yang akan dibangun dalam destinasi wisata di Sumenep ini Ronny menjawab sebagai berikut: Kami melihat dan berkunjung langsung ke tempat-tempat yang wisatanya sudah maju seperti Bali dan Banyuwangi, contohnya jika kita melihat Bali, tantangannya di Sumenep adalah kita tidak bisa meniru konsep seperti di Bali karena budaya di Bali dengan di Sumenep berbeda. Sehingga kami mencoba mencari apa yang bisa di terapkan di Sumenep Madura. (Wawancara, Ronny Arif, Kepala Bagian Promosi)

Dari Pernyataan tersebut dapat dijelaskan bahwa dalam membangun citra destinasi wisata di Sumenep, yang dilakukan oleh Dinas Pariwisata dan Kebudayaan melalui kepala bidang promosinya mencoba untuk mencari masukan dari tempat-tempat wisata di Indonesia yang sudah maju yang nantinya akan dilihat apa yang bisa di implementasikan ke dalam konsep dalam membangun citra destinasi wisata Sumenep.

Dalam hal membangun citra destinasi wisata budaya di Sumenep menurut apa yang disampaikan oleh Ronny Arif bagian kepala promosi mengatakan bahwa Sumenep ingin dikenal sebagai destinasi wisata yang enak dan nyaman untuk dikunjungi wisatawan. Oleh karena itu Sumenep juga mempunyai tagline the soul of madura dan mulai memperkenalkan kota Sumenep sebagai kota keris. Sedangkan berkaitan dengan pemanfaatan festival sebagai media komunikasi dalam membangun citra destinasi wisata budaya, Ronny Arif menyampaikan:

Kami menggunakan festival agar lebih dapat menarik perhatian masyarakat, karena target kami selain untuk menarik wisatawan luar, kami juga mengharapkan bahwa masyarakat kami juga sadar dan memahami bahwa budaya kita sendiri juga tidak kalah menarik dengan budaya-budaya luar. Sehingga harapan kami nantinya 
masyarakat juga ikut dalam menyebarkan informasi kepada sanak saudaranya yag ada diluar Sumenep. (Wawancara, Ronny Arif, Kepala Bagian Promosi)

Berdasarkan wawancara tersebut pemanfaatan festival dilakukan karena dianggap dapat menarik perhatian lebih pada masyarakat, sehingga dengan adanya festival diharapkan akan mendapatkan respon sesuai dengan apa yang menjadi tujuan Dinas Pariwisata dan Kebudayaan Sumenep. Dilihat dari proses komunikasi menurut Laswell mengenai "in what channel?" Pihak Dinas Pariwisata dan Kebudayaan memilih festival sebagai media penyampaian pesan karena dianggap pesannya akan lebih berpeluang untuk dapat disampaikan. Selain itu mengacu pada model komunikasi Aristoteles, yang mengatakan bahwa agar pesan persuasif dapat tersampaikan dengan baik maka salah satu yang perlu diperhatikan adalah kredibilitas dari komunikator, dalam hal ini yang menyampaikan pesan melalui media festival adalah Dinas Pariwisata dan Kebudayaan yang dimana sebagai komunikator sudah sangat kredibel karena memang itu menjadi kewenangan dari Dinas Pariwisata dan Kebudayaan. Dengan mengetahui bahwa yang membuat festival adalah Dinas Pariwisata dan Kebudayaan maka masyarakat selaku komunikannya akan lebih perhatian terhadap acara tersebut.

Menyinggung mengenai pesan apa saja yang ingin disampaikan melalui festival tersebut agar citra yang akan dibangun sesuai dengan apa yang diharapkan oleh Dinas Pariwisata dan Kebudayaan Sumenep, berikut kutipan wawancaranya:

Dengan menggunakan festival pesan yang ingin kami sampaikan kepada masyarakat yaitu Sumenep memiliki beragam budaya yang unik dan menarik yang tidak ada di tempat-tempat lain. Oleh karena itu kami menampilkan budaya-budaya khas Sumenap dalam rangkaian acara festival Sumenep disepanjang tahun 2018 ini. Seperti Musik Tong-tong, Musik Saronen, Kerapan Sapi, Sapi Sonok dan lain sebagainya. (Wawancara, Ronny Arif, Kepala Bagian Promosi)

Mendasar pada pernyataan tersebut dapat diartikan penggunaan festival digunakan sebagai media untuk menyampaikan pesan bahwa Sumenep adalah tempat yang memiliki budaya yang unik yang tidak ditemukan di daerah lain. Hal tersebut ditunjukkan dengan menampilkan budaya-budaya khas Sumenep dalam rangkaian acara festival yang diselenggarakan oleh Dinas Pariwisata dan Kebudayaan Sumenep. Berikut kalender kegiatan festival atau acara yang diselenggarakan oleh Dinas Pariwisata dan Kebudayaan Sumenep:

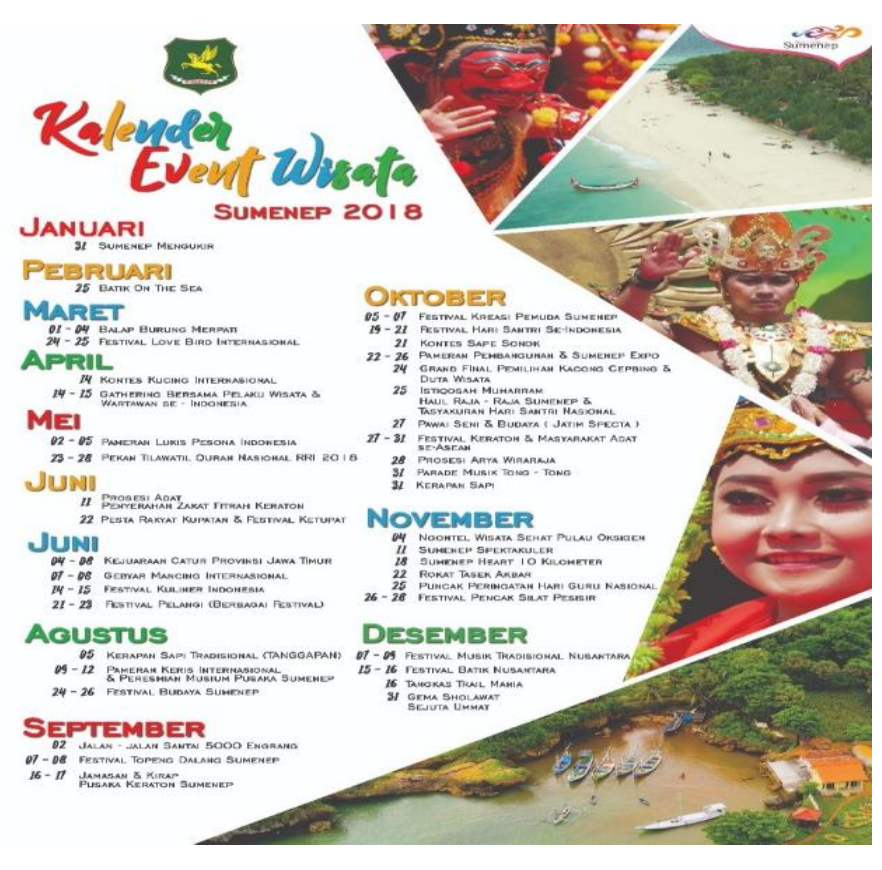

Gambar 1. Kalender Visit Sumenep 2018

Sumber: archipelago-indonesia (2018) 
Selain itu acara atau festival yang digunakan sebagai media penyampaian pesan salah satunya adalah kontes sapi sonok yang diadakan pada bulan Oktober 2018.

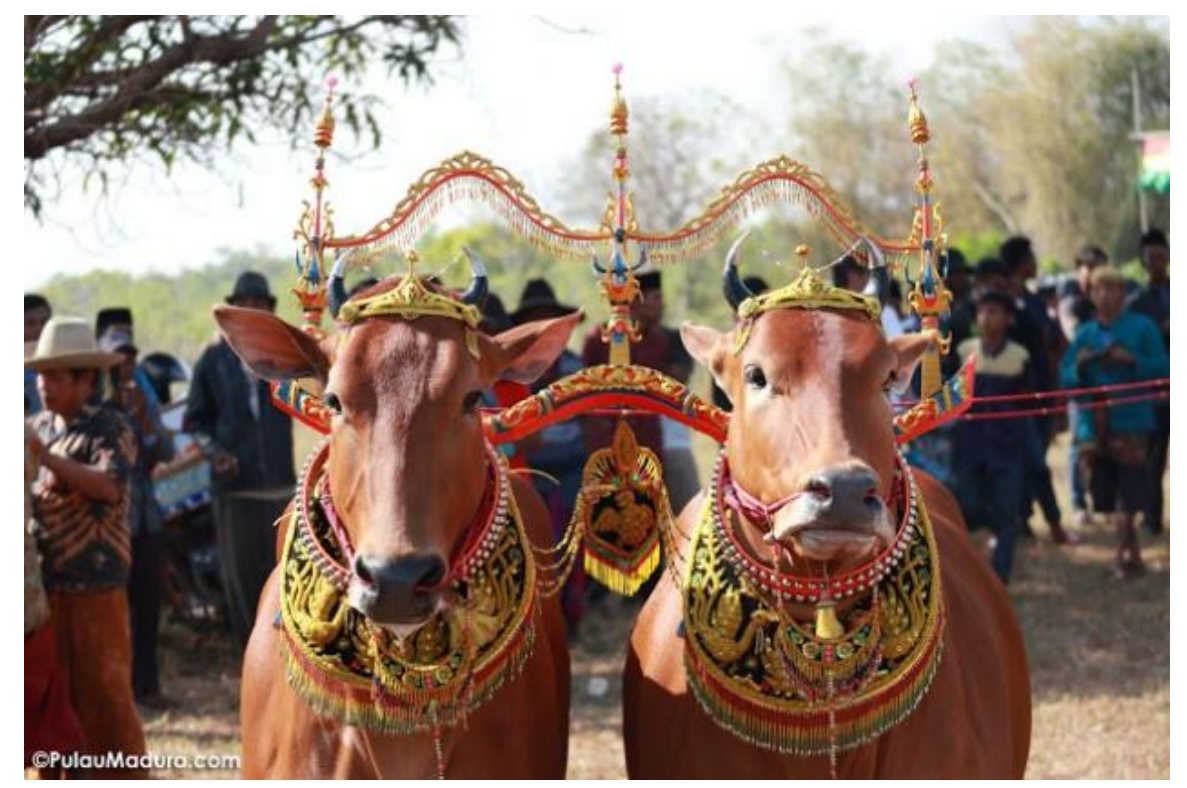

Gambar 2. Budaya Sapi Sonok

Sumber: Info Madura (2015)

Sejarah dari budaya Sapi Sonok ini dikenal bermula dari adanya suatu kebiasaan para petani di Madura dalam merawat sapi-sapi ternak. Pada setiap sore hari sapi - sapi ternak milik petani ini khususnya yang sapi betina dimandikan oleh para pemilik sapi dan kemudian sapi-sapi tersebut diikat pada sebuah tonggak bambu atau kayu yang dimana sapi-sapi tersebut kemudian dijejer rapi oleh para petani.

Dari situlah muncul ide-ide yang unik yang tidak terpikirkan oleh para petani, yaitu melakukan pemilihan pada sapi-sapi yang berjejer di sawah tersebut untuk mencari mana sapi yang tercantik, mulus dan enak dipandang. Hal yang bermula dari keisengan tersebut lama-lama lambat laun ternyata dijadikan suatu kontes kecantikan sapi dari yang awalnya hanya pada tingkat perorangan, menjadi tingkat desa, kecamatan hingga kontes kecantikan sapi tingkat kabupaten.

Berbeda dengan kerapan sapi yang kebanyakan menggunakan sapi-sapi jantan dalam perlombaannya, pada budaya kontes sapi kecantikan atau sapi sonok ini sendiri lebih cenderung menggunakan sapi betina. Pada awal-awal perkembangan ketika digunakan dalam perlombaannya budaya kontes Sapi Sonok cukup sekedar dinilai dari fisik atau kondisi sapinya saja, akan tetapi seiiring berjalannya waktu penilaian budaya kontes kecantikan sapi ini mulai menilai tidak hanya dari segi fisik saja akan tetapi juga menilai dari keserasian sepasang sapi betina beserta aksesoris-aksesoris yang digunakan pada sapi tersebut.

Mengenai harga jual untuk sapi yang memenengkan sapi sonok ini tidak jauh berbeda dengan sapi yang memenangkan perlombaan dari budaya kerapan sapi. Sapi pemenang dari kontes sapi sonok ini memiliki harga yang melambung tinggi. Harganya sendiri dapat melambung sampai ratusan juta rupiah. Kadang sapi-sapi yang mengikuti kontes sapi sonok ini juga disebut sebagai sapi elit Madura karena harganya yang tinggi.

Ada juga festival kerapan sapi yang diadakan pada bulan Agustus 2018. Kerapan sapi ini adalah suatu perlombaan balapan sapi dimana dalam perlombaan menggunakan sepasang sapi jantan yang dibekalangnya menarik semacam kereta yang berbahan kayu yang digunakan oleh orang yang menunggangi sapi tersebut yang kemudian beradu kecepatan dengan melawan pasangan sapi yang lainnya.

Kerapan sapi ini berawal dari ketekunan mengenai membajak sawah dengan menggunakan sapinya untuk bekerja dipulau sapudi, Sapi-sapi digunakan untuk mengolah sawah yang ternyata berhasil, dari tanah yang tandus berubah menjadi tanah subur. Pada akhirnya tanah di seluruh Pulau Sapudi yang awalnya gersang, berubah menjadi tanah subur yang bisa ditanami oleh padi. 


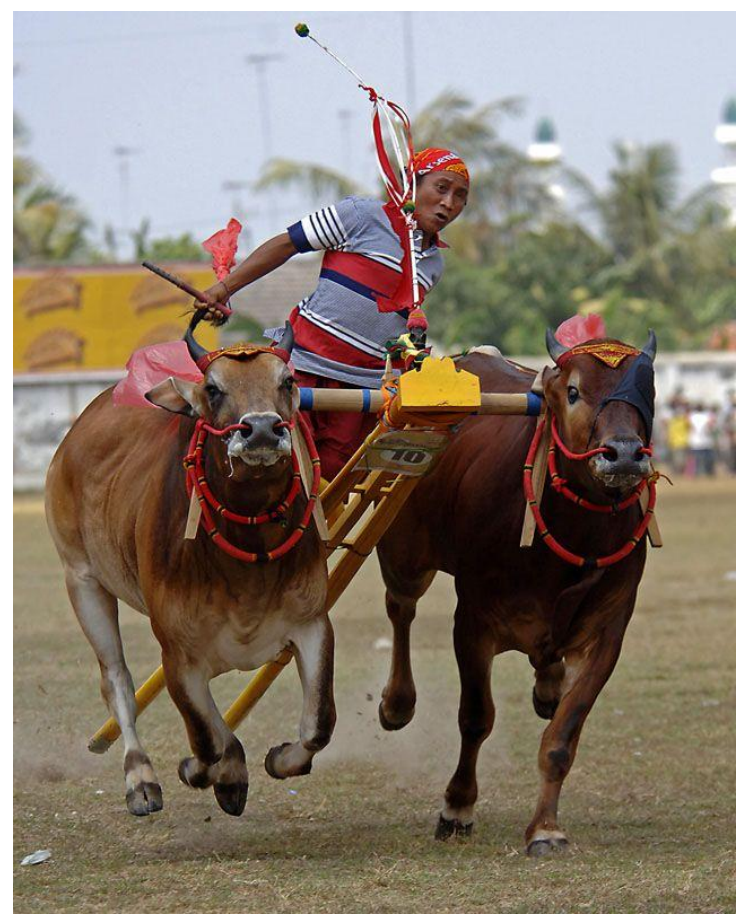

Gambar 3. Budaya Kerapan Sapi

Sumber: Info Madura (2015)

Setelah padi-padi tersebut memasuki musim panen maka sebagai ungkapan terima kasih atas hasil panen yang melimpah. Pangeran Ketandur menyampaikan idenya untuk mengajak penduduk di desanya mengadakan pacuan sapi. Tanah sawah yang ditanami padi yang sudah dipanen digunakan untuk area pacuan sapi yang pada akhirnya tradisi pacuan sapi yang bermula dari gagasan Pangeran Ketandur inilah yang hingga kini terus berkembang dan dilestariannya. Dan sekarang dikenal dengan kerapan sari. (Lontar Madura, 2011)

Berikutnya ada festival parade musik tong-tong. Pada awal perkembangannya, musik tong-tong ini biasa digunakan penduduk Madura untuk membangunkan warga ketika sahur pada bulan puasa atau ramadhan dengan tujuan agar orang tidak keterusan tidur, selain itu juga sering digunakan untuk jaga malam atau ronda.

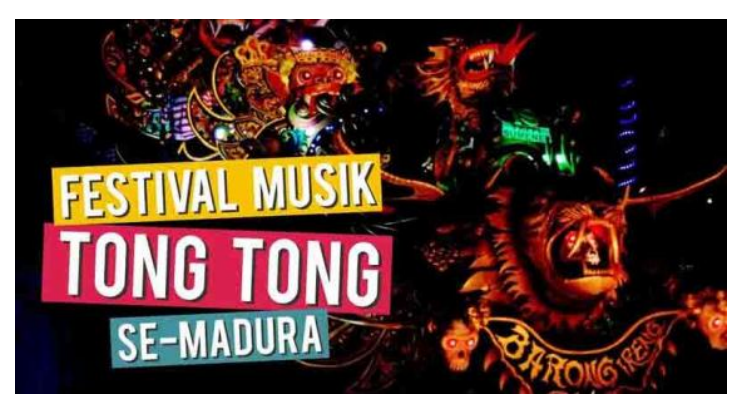

Gambar 4. Budaya Musik Tong-tong

Sumber: Mardiayanto (2018)

Musik tongtong atau kentongan terbuat dari bahan kayu ataupun bambu, Tong-tong awalnya hanya memiliki tiga jenis nada, dimana nada tersebut terdiri dari nada rendah, nada sedang dan nada tinggi. Biasanya musik tong-tong ini dimainkan dengan cara ditekok keras, tetapi seiring dengan perkembangan musik ini dimainkan berbarengan dengan alat-alat musik yang lainnya. Alunan musik yang dihasilkan yang bertalu-talu inilah yang menunjukkan ungkapan kegembiraan penduduk madura. (Mardiyanto, 2018)

Ada lagi salah satu budaya musik madura yang disebut sebagai musik saronen. Budaya musik saronen adalah musik khas Madura yang memiliki karakteristik yang khas yang terdiri dari sembilan instrumen musik yang khas. Kesembilan instrumen musik saronen ini terdiri dari : 1 saronen, 1 gong besar, 1 kempul, 1 satu kenong besar, 1 kenong tengahan, 1 kenong kecil, 1 korca, 1 gendang besar, 1 gendang kecil. 
Musik saronen sejumlah sembilan dikarenakan hal tersebut disesuaikan dengan nilai filosofis Islam yang merupakan kalimat pembuka dari Alqur'an yaitu "bismillahhirrahmanirrahim" yang kalau diucapkan terdiri dari sembilan ejaan yaitu bis mil lah hir rah ma nir ra him. Hal tersebut merupakan dampak dari budaya musik saronen yang pada perkembanganya digunakan untuk media dakwah agama islam. (Romadhan, 2018)

Saronen yang merupakan suatu kombinasi tarian dan musik yang berasal darikota sumenep ini, biasanya dimainkan secara berkelompok yang terdiri dari terompet, gong, rebana dsb yang dimainkan dengan cara berdiri diiringi musik saronen serta lenggak-lenggok para pemain rebana dan gong sambil menabuh gendang dan meniup terompet, biasanya Saronen ditampilkan ketika acara pesta rakyat, syukuran rakyat, karapan sapi, penyambutan tamu dsb. (Ahsan, 2012)

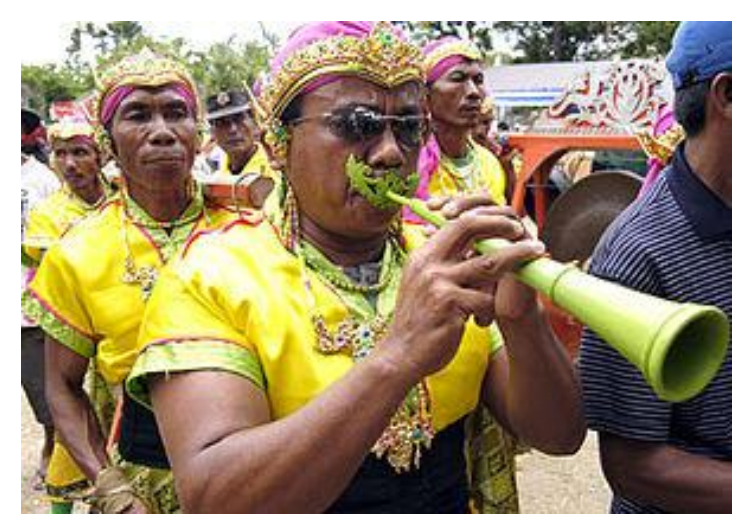

Gambar 5. Budaya Musik Saronen Sumber: Romadhan (2017)

Yang paling besar dari rangkaian festival di visit Sumenep 2018 adalah festival keraton dan masyarakat adat se-ASEAN. Indonesia sendiri merupakan pemilik keraton terbanyak di ASEAN maupun di dunia hingga saat ini. (Tribun News, 2018)

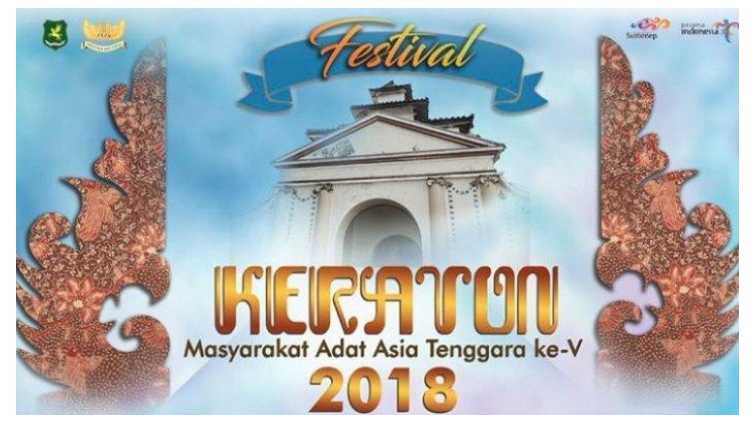

Gambar 6. Festival Keraton

Sumber: Tribun News (2018)

Keraton itu sendiri merupakan sumber kebudayaan yang melahirkan karya-karya seni yang luhur sebagai representasi identitas dari negara dan budaya bangsa yang merupakan aset penting nasional yang berpotensi di bidang kepariwisataan Sekaligus sebagai media pelestarian budaya dan mempromosi pariwisataan yang ada indonesia khususnya Sumenep di tahun 2018 ini.

Festival Keraton Nusantara 2018 telah masuk dalam event pariwisata nasional Tahun 2018 yang bertujuan untuk mendorong kunjungan wisatawan khususnya di Sumenep, Provinsi Jawa Timur sehingga pada akhirnya mampu meningkatkan kesejahteraan masyarakat setempat. Festival ini diadakan untuk pertama kalinya di Surakarta, Jawa Tengah, pada tahun 1992. Pada saat itu, hanya istana yang ada di Pulau Jawa. (Pedoman Wisata, 2018)

Pada teori manajemen impresi disebutkan bahwa interaksi sosial setiap individu berupaya menampilkan gambaran dirinya atau konsep dirinya di depan orang lain, hal tersebut dapat dikatakan sebagai upaya individu yang secara sengaja menggunakan komunikasi untuk menciptakan impresi yang diinginkan dari orang lain terhadapnya. Dalam konteks organisasi pada Dinas Pariwisata dan Kebudayaan Sumenep 
yang ingin membangun citra destinasi wisata budaya di Sumenep untuk menggambarkan sebagai tempat yang memiliki beragam budaya maka ditampilkanlah budaya khas Sumenep dalam festival tersebut agar masyarakat atau khalayak yang melihat memiliki impresi yang sama sesuai dengan yang diinginkan oleh Dinas Pariwisata dan Kebudayaan Sumenep.

Berdasarkan yang dikemukan Goffman dalam proses manajemen impresi untuk mengelola impresi khalayak cenderung menggunakan komunikasi verbal karena dianggap mudah untuk dikelola dibandingkan komunikasi non verbal. Dalam kasus Dinas Pariwisata dan Kebudayaan Sumenep hal tersebut ditunjukkan dengan membuat kalender dengan tulisan Calender of Event Visit Sumenep 2018. ada juga ditunjukkan dengan menampilkan tagline the soul of Mandura. akan tetapi khusus dalam penyampain pesan dengan menggunakan media Dinas Pariwisata dan Kebudayaan Sumenep menggunakan komunikasi non verbal dengan menampilkan suguhan budaya-budaya yang ada di Sumenep seperti Kerapan Sapi, Sapi Sonok, Musik Tong-tong dan Musik Saronen

Berkaitan dengan alasan mengapa budaya yang dipilih untuk mencerminkan budaya khas Sumenep adalah kerapan sapi, sapi sonok, musik tong-tong, musik saronen menurut Ronny arif menyampaikan sebagai berikut:

Pertama kenapa kerapan sapi dan sapi sonok, karena Madura memang dari dahulu kala dikenal karena karakteristik sapi merah. Semua orang hampir semuanya mengatui bahwa sapi merah adalah sapi madura. Bahkan di pulau Sepudi dikenal dengan pulau sapi karena memang banyak peternak sapi di pulau tersebut. Sedangkan saronen karena musiknya yang kencang dan tariannya yang enerjik yang menandakan karakteristik dari orang madura dan pakaian yang digunakan dalam musik saronen tersebut warna warni dan cenderung terang. Itu juga menunjukkan karakteristik dari orang madura. (Wawancara, Ronny Arif, Kepala Bagian Promosi)

Berdasarkan pernyataan tersebut dapat dijelaskan bahwa untuk dalam teori manajemen impresi cara mempresentasikan sumenep sebagai destinasi yang memiliki banyak budaya yang unik dan menarik yang dilakukan oleh Dinas Pariwisata dan Kebudayaan Sumenep dengan cara menunjukkan budaya-budaya yang memang dikenal sebagai budaya khas Sumenep akan tetapi lebih dikonsep modern dengan menggunakan media festival agar dapat diterima dalam masyarakat jaman sekarang terutama anak-anak muda. Sedangkan dilihat dari kelima strategi presentasi diri menurut Edward Jones dalam kriyantono (2014), cara yang dilakukan Dinas Pariwisata dan Kebudayaan cenderung menggunakan strategi promosi diri (self-promotion).

\section{KESIMPULAN}

Pada proses membangun citra sebagai destinasi wisata budaya melalui media komunikasi festival yang dilakukan oleh Dinas Pariwisata dan Kebudayaan, upaya yang dilakukan dengan menunjukkan dan menampilkan budaya-budaya khas yang dimiliki oleh Sumenep seperti kerapan sapi, sapi sonok, musik tongtong, musik saronen untuk dipresentasikan kepada masyarakat luas dengan bertujuan untuk menghasil impresi yang sesuai dalam persepsi masyarakat. Pilihan festival sebagai media komunikasi untuk penyampaian pesan dianggap tepat agar dapat menarik animo masyarakat. Dan strategi presentasi diri lebih menekankan pada strategi promosi diri (self-promotion).

\section{DAFTAR PUSTAKA}

Ahsan, A. F. (2012). Harapan Bagi Saronen. Diakses pada tanggal 5 November 2018 dari http://platm.com/harapan-bagi-saronen/

Cresswell, J. W. (2015). Penelitian Kualitatif \& Desain Riset Memilih di Antara Lima Pendekatan. Yogyakarta: Pustaka Pelajar.

Goffman, E. (1959). The Presentation of Self in Everyday Life. New York: Doubleday

Info Madura (2015). Sejarah, Tradisi dan Kontes Sapi Sonok di Madura. Diakses pada tanggal 15 November 2018 dari https://www.pulaumadura.com/2015/10/sejarah-tradisi-dan-kontes-sapi-sonok. html

Kemendikbud. (2018). Badan Bahasa Petakan 652 Bahasa Daerah di Indonesia. Diakses pada tanggal 9 November 2018 dari https://www.kemdikbud.go.id/main/blog/2018/07/badan-bahasa-petakan-652bahasa-daerah-di-indonesia 
Kemendikbud. (2018). Kemendikbud Tetapkan 225 Warisan Budaya Takbenda. Diakses pada tanggal 9 November 2018 dari https://www.kemdikbud.go.id/main/blog/2018/10/ kemendikbud-tetapkan-225warisan- budaya-takbenda

Kriyantono, R. 2010. Teknik Praktis Riset Komunikasi. Jakarta: Kencana.

Kriyantono, R. 2014. Teori Public Relations Perspektif Barat dan Lokal. Jakarta: Kencana.

Lontar Madura (2011). Karapan Sapi, Tradisi, Pesta, dan Prestise Rakyat Madura. Diakses pada tanggal 19 November 2018 dari http://www.lontarmadura.com/ sejarah-karapan-sapi/

Mardiyanto, A. (2017). Ingat, Ada Festival Musik Tong-Tong Malam Ini Lho. Diakses pada tanggal 8 November 2018 dari https://visitsumenep.com/ingat-ada-festival-musik-tong-tong-malam-ini-lho/

Moerdijati, S. (2012). Pengantar Ilmu Komunikasi. Surabaya: Revka Petra Media

Moleong, L. J. 2013. Metode Penelitian Kualitatif. Edisi Revisi. Bandung : PT. Remaja Rosdakarya

Mulyana, D. (2016). Ilmu Komunikasi, Suatu Pengantar. Bandung: Remaja Rosdakarya.

Pedoman Wisata (2018). Festival Keraton Nusantara (FKN) 2018 di Sumenep : Momen Berkumpulnya Semua Kerajaan Nusantara. Diakses pada tanggal 11 November 2018 dari https://www. pedomanwisata.com/event/festival/festival-keraton-nusantara-fkn-2018-di-sume nep-momenberkumpulnya-semua-keraj aan-nusantara

Romadhan, M. I. (2018). Pemanfaatan Budaya Lokal Saronen Dalam Proses Manajemen Public Relations. Jurnal Representamen: Jurnal Ilmiah Kajian Komunikasi, Vol. 04(01), hal. 41-46

Romadhan, M. I., Puspaningtyas, A., Rahmadanik, D. (2018). Strategi Komunikasi Dalam Pelestarian Budaya Saronen Kepada Generasi Muda Di Kabupaten Sumenep. Jurnal Representamen: Jurnal Ilmiah Kajian Komunikasi, Vol. 04(02), hal. 70-78

Rosenfeld, P., Giancalone, R., \& Riordan, C.A. (1994). Impression Management Theory and Diversity: Lesson for Organizational Behaviour. American Behavioral Scientist, 37, 601-604.

Tribun News. (2018). Festival Keraton ASEAN akan Digelar, Tagar \#PesonaKeratonNusantara2018 jadi Trending Topic Twitter. Diakses pada tanggal 13 November 2018 dari http://travel.tribunnews.com/2018/10/14/festival-keraton-asean-akan-digelar-taga $\quad$ rpesonakeratonnusantara2018-jadi-tren ding-topic-twitter?page $=1$

Wimmer, R. D \& Joseph R. D. (2000). Massa Media Research: An Introduction Sixth Edition. Belmont: Wadswort Publishing Company. 